\title{
Oglądanie poezji. Retrospektywa subiektywna
}

\author{
Viewing of poetry. A subjective retrospective \\ Paweł WOJCIECHOWSKI ${ }^{1}$ \\ Uniwersytet w Białymstoku
}

\begin{abstract}
Streszczenie
$\mathrm{W}$ artykule ukazano zmieniający się paradygmat słowa poetyckiego w dobie późnej nowoczesności. W obecnym momencie kulturowym, w rzeczywistości technocentrycznej słowo nie znaczy już tyle, ile znaczyło we wcześniejszym dziedzictwie humanistycznym, w kolosalnym dorobku myśli ludzkiej. Zmiana, którą tutaj uwyraźniam, zainicjowała poważny proces transfiguracji słowa (nie jego deprecjacji), którego różnoimiennych implikacji doświadcza dzisiejsza kultura. W niniejszym artykule namysł skierowano na ponowoczesną innowację lingwistyczną, której efektem jest poezja cybernetyczna. Uchwycono rozwój nowatorskiego projektu „słowa” cybernetycznego, wobec którego wyszła naprzeciw poezja tradycyjna. W związku z tym wyjaśniono kim jest dzisiaj poeta cybernetyczny i czym jest tworzona przez niego: wideopoezja, cyfrowa poezja konkretna i wizualna, poezja dźwiękowa oraz poezja hipertekstowa. Z osadzonych w tekście namysłów wyłania się nader intrygująca i pociągająca idea prekursorskiego i alternatywnego alfabetu cyfrowego jako kompozytu poezji ultranowoczesnej.
\end{abstract}

Słowa kluczowe: poezja cybernetyczna, późna nowoczesność, słowo, alfabet cyfrowy

\begin{abstract}
1 https://orcid.org/0000-0001-8826-5318

Uniwersytet w Białymstoku, Wydział Filologiczny

p.wojciechowski@uwb.edu.pl
\end{abstract}

The article displays the changing paradigm of the poetic word in the era of late modernity. In the current cultural moment of the tech-centric era, the word is not as powerful as it was throughout the earlier humanistic heritage and throughout the colossal achievements of human thought. The change I have accentuated here has initiated a major process of transfiguration of the word (not of its depreciation), the multidirectional implication of which is experienced by today's culture. This article directs thought towards the postmodern linguistic innovation, 
the effect of which is cybernetic poetry. It captures the development of the innovatory project of the cybernetic "word", which has now been challenged by traditional poetry. In regard to this matter, today's definition of a cybernetic poet was presented, along with the video poetry, tangible and visual digital poetry, audio poetry and hypertext poetry created by the poet. The thoughts included in the text erect a quite an intriguing and appealing idea of a precursory and alternative digital alphabet as a composite of ultra-modern poetry.

Keywords cybernetic poetry, late modernity, word, digital alphabet

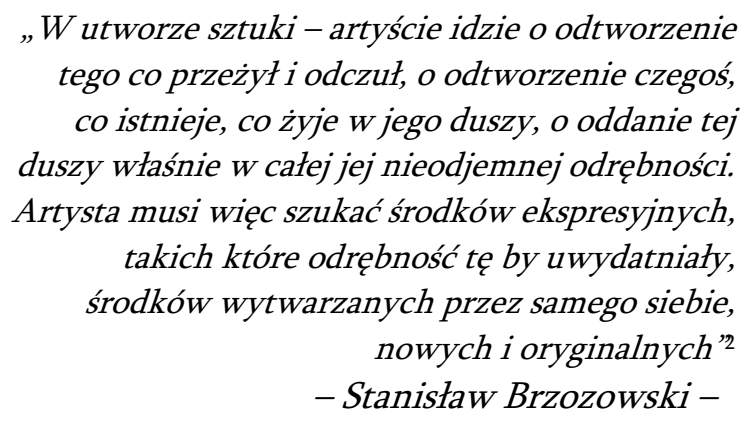

\section{Wprowadzenie}

Twórczość poetycka stanowi stały element koncepcyjnej działalności człowieka, jego aktywności intelektualnej i artystycznej. Prymarnymi warunkami tej działalności powinny być: innowacyjność i niekonwencjonalność. Pozwalają one zatrzymywać indywidualną percepcję na nowych wartościach stymulujących rozwój jednostek oraz dostrzec twórcę, jego osobowość, talent, prezentowaną przezeń nową jakość, którą wnosi w przestrzeń złożonych procesów holistycznego rozwoju kultury.

Przywołane wyżej słowa filozofa, teoretyka kultury, pisarza i publicysty Stanisława Leopolda Brzozowskiego (1878-1911) - motto niniejszego tekstu stanowią istotny przyczynek $\mathrm{ku}$ badaniom komparatywnym podjętym w studium. W uchwyconej przez autora Kultury i życia perspektywie, pragnę spojrzeć na wytwory poetyckie powstałe na przełomach wieków: XIX/XX i XX/XXI i „obejrzeć” ich formy, odnajdując w nich ponadindywidualną ekspresję i specyficzność. Tytułowa formuła 'oglądania' wierszy odsłoni, jak sądzę, zaskakującą bliskość $\mathrm{w}$ polu komparacji, przemiany, zabawy i modernizacyjnej informatyzacji słowa poetyckiego. Wektor badawczy prowadzę głównie w odniesieniu do poezji polskiej wskazanych okresów, nie

\footnotetext{
${ }^{2}$ Stanisław Brzozowski, Estetyka poglądowa (1902, s. 444).
} 
unikając odniesień do interesujących i dystynktywnych przykładów z innych europejskich obszarów literaturowych, nauk poetycznych.

\section{Spojrzenie w druk (przykłady $\mathrm{z}$ różnych epok)}

$$
\begin{array}{r}
\text { „Na poezji powinna oprzeć się sztuka - } \\
\text { poezją winna oddychać- } \\
\text { powinna być jej siostrą najmilszą, najbliższą jej sercu’3 } \\
- \text { Tadeusz Seweryn - }
\end{array}
$$

Poezja wizualna należy do niekonwencjonalnego rodzaju literatury, dlatego od dawna wzbudza zainteresowanie badaczy różnych dyscyplin filologicznych, artystycznych i przede wszystkim odbiorców. Zwłaszcza w dzisiejszej dobie interdyscyplinarnej - czasie dominacji technologii informatycznych, sztuki intermedialnej, zainteresowania cyberprzestrzenią, o czym będzie mowa w drugiej części niniejszego studium. Poezja wizualna ma bogatą tradycję, z uwagi na jej materię, zasadniczo nieograniczone możliwości konfiguracji obrazu i słowa (zob. Rypson, 1989; 2002). Wiersz wizualny (pattern poem) ma prostą budowę. Składa się z jednej albo większej ilości zwrotek, zdań, słów, które są wbudowane $\mathrm{w}$ określony, wybrany przez autora kształt, odpowiadający treści utworu (Wilczek, 1989, s. 43-44).

Historia poezji wizualnej ,jest dłuższa niż historia literatury w ogóle: problemy związane $\mathrm{z}$ obrazowością pisma, nadawaniem kształtu literom i pojęciom - a więc problemy tkwiące u genezy poezji wizualnej - nurtowały ludzkość od jej początków" (Wilczek, 1989, s. 45). Wczesne typografie druku poetyckiego spotykamy $\mathrm{w}$ antyku, w epigrafice starożytnej (greckie technopaegnia (Rypson, 2002, s. 11-25): techne - sztuka, paegnion - gra, zabawa; oryginalne utwory, prezentujące wiersz w odpowiedniej formie, np. krzyża, jaja, skrzydeł [słynne utwory Symiasza], kwiatów), potem w średniowieczu (od Hrabana Maura przez wiersz przestrzenno-liniowy po wiersze diagramowe, wizualne Nicola de'Rossiego i Jacobusa Nicholai de Dacia (Rypson, 2002, s. 25-35). W kolejnych epokach należy odnotować w Europie wysokie zainteresowanie tego typu aktywnością twórczą, aż po wiek XIX, kiedy to zaangażowanie maleje.

Z recepcyjnego punktu widzenia szczególnie efektowna, medialna i ważna jest twórczość Hrabana Maura (Magnentius Hrabanus Maurus, Rabanus Maurus, ok. 780-856) - niemieckiego teologa i pisarza encyklopedycznego. Jego

${ }^{3}$ Tadeusz Seweryn, Indywidualność plastyczna Wyspiańskiego (1932, s. 8). 
arcyciekawa księga Liber de laudibus sanctae crucis (815 r.) stanowi doskonały przykład wczesnośredniowiecznej poezji wizualnej. Innowacją pisarza były imago poem ${ }^{4}$, nieprzeciętna troska o szczegóły, kształt oraz umiejętnie i koncepcyjnie wykorzystywana na potrzeby twórczości numerologia i palindromy. Aktywność twórcza oryginalnego Hrabana przyczyniła się na przestrzeni wieków w Europie „do powstania wielkiego repertuaru wierszy w kształcie krzyża, występującego w poezji wizualnej w formie intekstu, raz jako wiersz figuralny (wypełniony tekstem), to znów układany bywa za pomocą techniki wiersza przestrzenno-liniowego" (Rypson, 2002, s. 48). Oto kilka przykładów:

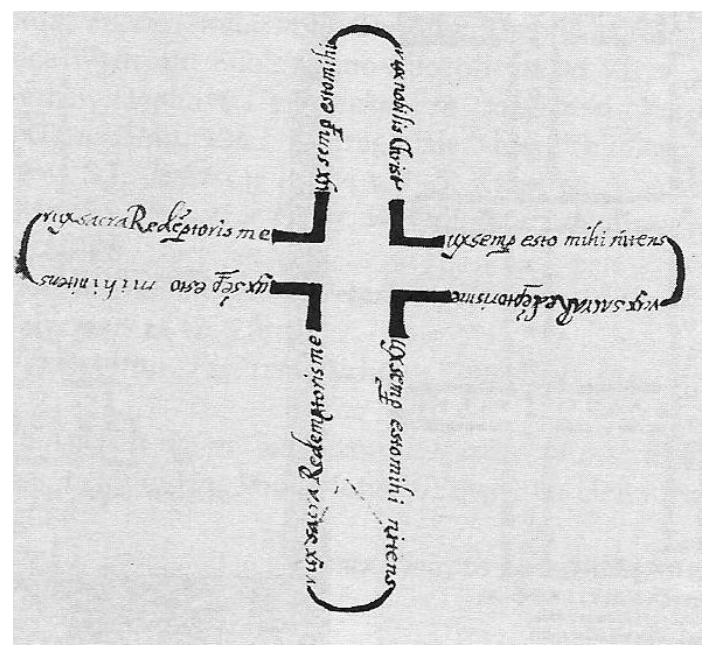

Krzyż - wiersz przestrzenno-liniowy ${ }^{5}$

Krzyż - wiersz figuralny ${ }^{6}$

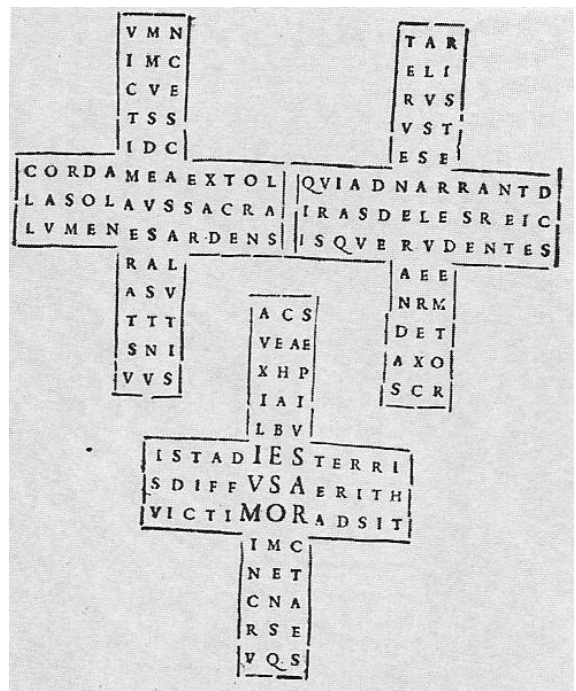

\footnotetext{
${ }^{4}$ Figura wykorzystująca zarys prostokąta, w który autor wpisuje słowa. W jego obrębie pojawiają się inteksty (czyli wersy wpisane $\mathrm{w}$ tekst główny utworu) już nie $\mathrm{w}$ formie akro- czy telestychów, ale jako pełne figury. Nietradycyjna forma łączy utwór słowny z miniaturami malarskimi.

${ }^{5}$ Rkps Akademia Nauk Bukareszt (ok. 1685), wiersz w języku łacińskim (Rypson, 2002, s. 260).

${ }^{6}$ Trzy krzyże Rabanianae artificiosae figurae - w języku łacińskim (Rypson, 2002, s. 261).
} 
Rozmaite kształty, formy krzyży były najpopularniejszymi odmianami poezji wizualnej na przestrzeni wieków. Pisali je niemal wszyscy znaczący w swoich czasach autorzy, od anonimowych poczynając, kończąc na protestantach (np.: Catherina von Greiffenberg, Robert Herrick), katolikach (np. Robert Angot) i prawosławnych (np. Iwan Wełyczkowski) (Rypson, 2002, s. 153). Ciekawie projektowano wiersze $\mathrm{w}$ kształcie krzyża pektoralnego (od pektorału napierśnika, łac. pectus. pierś; rodzaj biżuterii świeckiej lub religijnej noszonej na piersi, zapinanej od tyłu), krzyża akrostychowego (od akrostychu - utworu wierszowanego, w którym niektóre z kolumn liter, sylab, wyrazów dają dodatkowo całe wyrazy, frazy, zdania; kolumny te można czytać w dół, w górę, naprzemiennie), albo takie, które inkrustowano np. imionami książąt.

W drugiej połowie XVI stulecia poezja, którą można było „oglądać” zyskuje sobie olbrzymie grono odbiorców w różnych krajach europejskich. Sprzyjała temu moda na indywidualistów - autorów ścigających się w nowych konceptach wersyfikacyjnych. $\mathrm{Na}$ przestrzeni wieków poezja wizualna zajmowała poczesne miejsce we Francji, Włoszech, Niemczech, Anglii, Czechach, jak również w Polsce (z pewnym opóźnieniem w stosunku do pozostałych krajów). Wyróżniała się poezja kunsztowna, którą można sklasyfikować w następujące kategorie:

- Teksty, w których „gra językowa dotyczy układu słów lub liter w wersie albo w całym utworze" (Rypson, 2002, s. 56): akrostych; tautogram - tekst, w którym każdy wiersz lub każdy wyraz zaczyna się od tej samej litery; palindrom - gra słowna (dawniej o znaczeniu magicznym), wyrażenie brzmiące tak samo czytane od lewej do prawej i odwrotnie.

- Teksty, w których „gra językowa dotyczy permutacji elementów leksykalnych - liter w anagramie i słów w wierszu proteuszowym" (Rypson, 2002, s. 56).

- Teksty, w których „operacje językowe dotyczą związku liter i słów z liczbami” (Rypson, 2002, s. 56).

- Teksty wizualne, oparte na graficznym obrazie słów.

Z tych bazowych kategorii wyłaniają się niezwykle ciekawe przykłady utworów wizualnych. Forma kielicha okazuje się jedną $\mathrm{z}$ ulubionych i efektownych w druku?:

7 Wpis dedykacyjny poety barokowego, dyplomaty i tłumacza Daniela Naborowskiego (15731640), „ułożony w kształcie kielicha, do „albumu przyjaciół” Daniela Cramera, swego kolegi ze studiów w Norymberdze w 1593 roku" (Rypson, 2002, s. 65, grafika s. 270). 


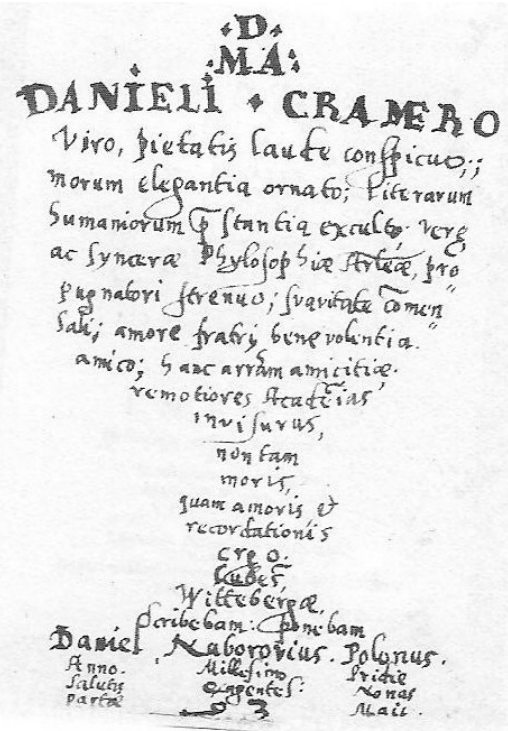

Są też liście, gwiazdy, drzewa - symbolizujące niepoznawalne energie natury, prawidła mechanizmu bytowego, wartości wynikające z tradycji. Nadto spotkać można: infuły, pastorały, pierścienie czy też piramidy (Rypson, 2002, s. 66-70), np.:

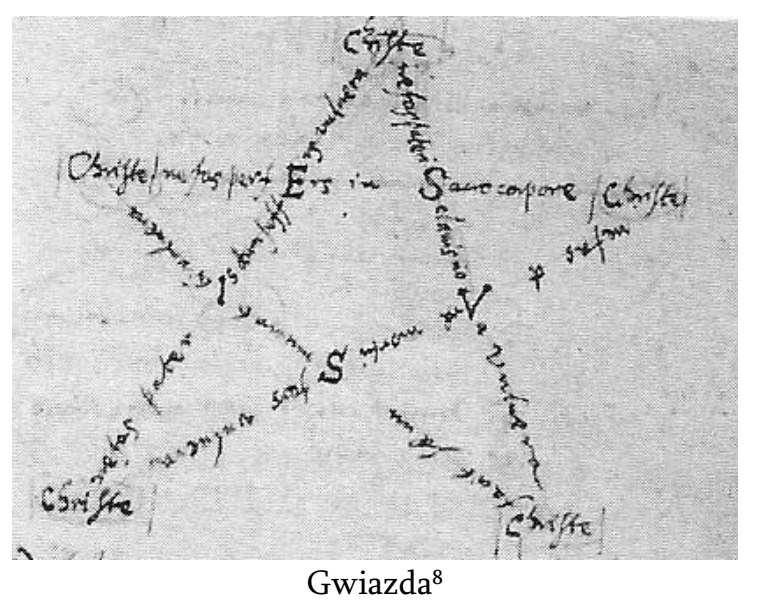

${ }^{8}$ Przełom XVI i XVII w. - w języku łacińskim (Rypson, 2002, s. 303). 


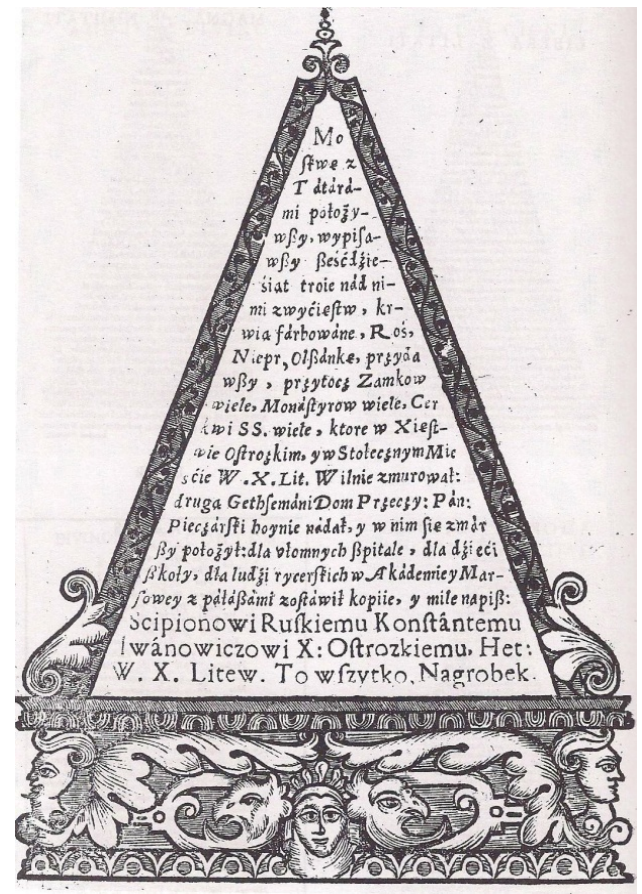

Piramida ${ }^{9}$

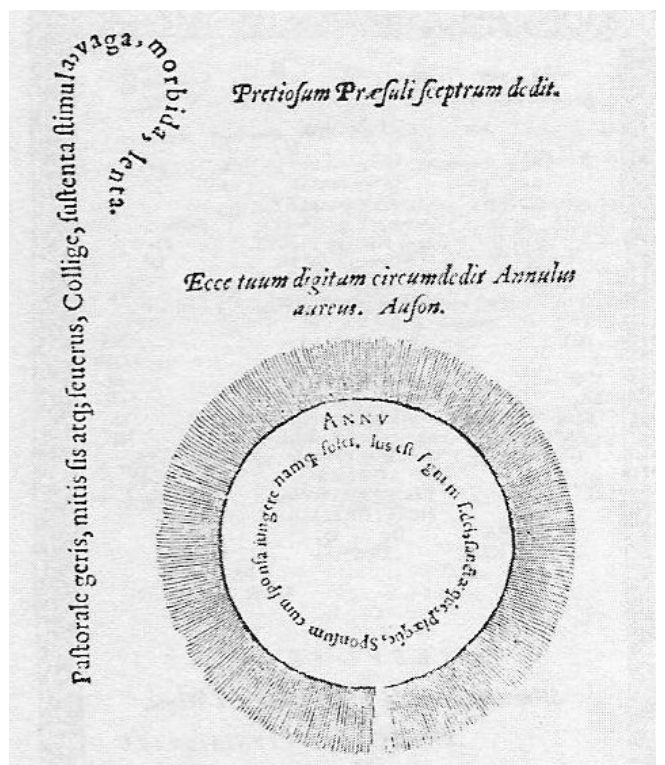

Pastorał ${ }^{10}$

9 Epitafium w drzeworycie ozdobnym dla księcia Konstantego Iwanowicza Ostrogskiego, hetmana wielkiego litewskiego - w języku polskim, 1638 r. (Rypson, 2002, s. 282). 
Do końca XIV stulecia świetnie funkcjonowały przedstawione wyżej wiersze przestrzenno-liniowe. Najważniejszy był w nich widoczny kształt pozbawiony tekstu. „Początkowo tworzono układy geometryczne tekstu, przede wszystkim koła i kwadraty, częstokroć podzielone przekątnymi. Autorzy wierszy w kształcie kół odwoływali się do symboliki kosmologicznej, stosując koło jako symbol świata, doskonałości i przemijania. Kwadrat natomiast oznaczał mądrość, stałość" (Rypson, 2002, s. 30-31).

W kolejnych epokach (szczególnie intensywnie w XVII wieku) dzięki rozmaitym przemianom historycznym, mentalnym, wzmożonej aktywności twórczej niezliczonych autorów i wykorzystywanych przez nich popularnych motywach o proweniencji np. religijnej, dużą popularnością cieszyły się $\mathrm{w}$ krajach europejskich labyrinthus poeticus (wiersze labiryntowe). W swojej wymowie uniwersalistycznej uwyraźniały meandry egzystencji człowieczej, rozumianą metaforycznie i dosłownie drogę życia doczesnego i duchowego. Korzeniami sięgają starożytności (Rzym, Egipt hellenistyczny), „W układzie labiryntu literowego zapisywano jeden wers lub dystych; czasem tylko jedno słowo. Wiersze takie cieszyły się dużą popularnością w baroku, zwłaszcza w Niemczech, Polsce, Hiszpanii i Portugalii" (Rypson, 2002, s. 173-174). Wśród tego rodzaju wierszy wyróżnia się: labirynty cubus, labirynt w kształcie krzyża, labirynty literowe romboidalne (złożone $\mathrm{z}$ jednego lub kilku słów), wiersze labiryntowe tautogramy, labirynty słowne:

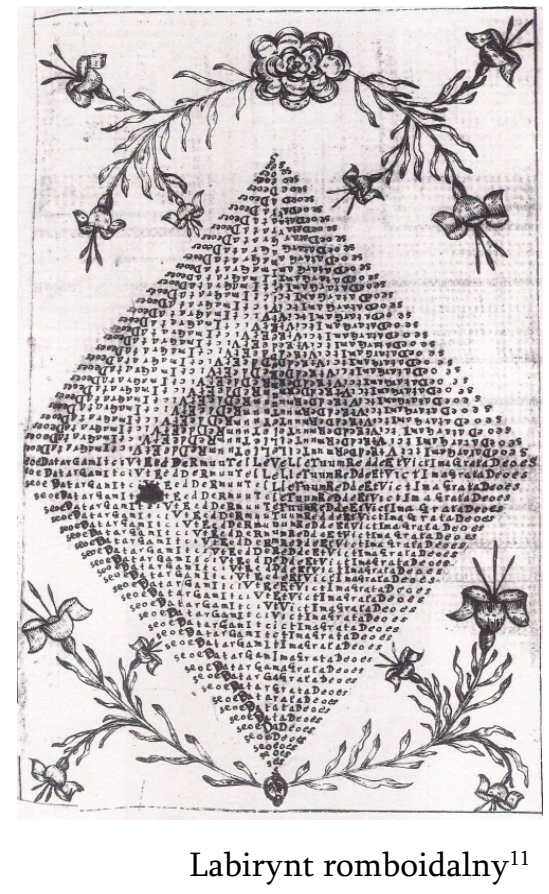

W tym nieustannym procesie powstawania nowych, koncepcyjnych form „druku poetyckiego”, wciąż poszukiwano innych, jeszcze bardziej odkrywczych i interesujących:

\footnotetext{
10 Wiersz przestrzenno-liniowy w języku łacińskim (1598) (Rypson, 2002, s. 269).

11 Wiersz labiryntowy literowy romboidalny złożony z kilku słów w języku łacińskim (1695) (Rypson, 2002, s. 328).
} 


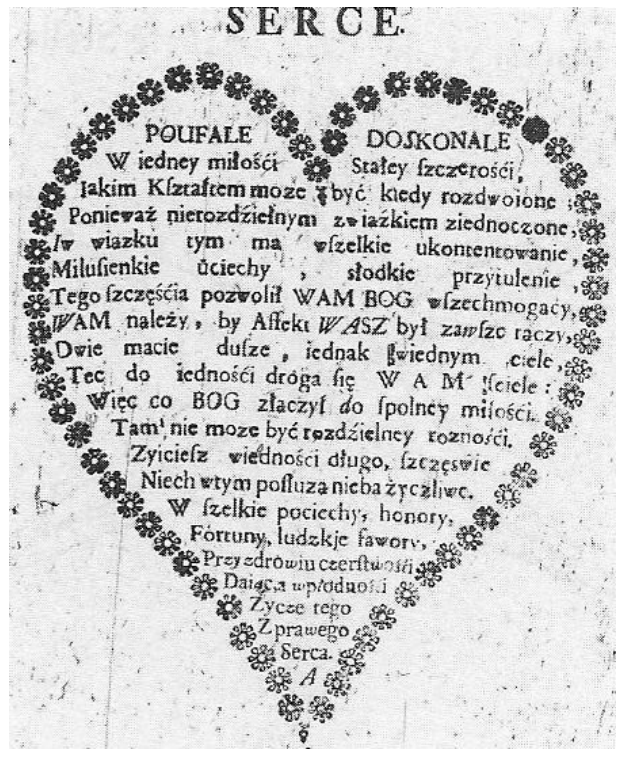

Wiersz w kształcie serca ${ }^{12}$

Wśród najbardziej zaskakujących konceptów wskazać należy wiersze w kształcie: ołtarza, owoców, kwiatów, pierścienia, rozmaitych form architektonicznych, herbów, chorągwi, serca, planet, zegarów, korony, form geometrycznych, drzew. Najpełniej widać to w bogatej, „kwiecistej” epoce europejskiego baroku. Przykłady:

Wiersz wizualny ${ }^{13}$

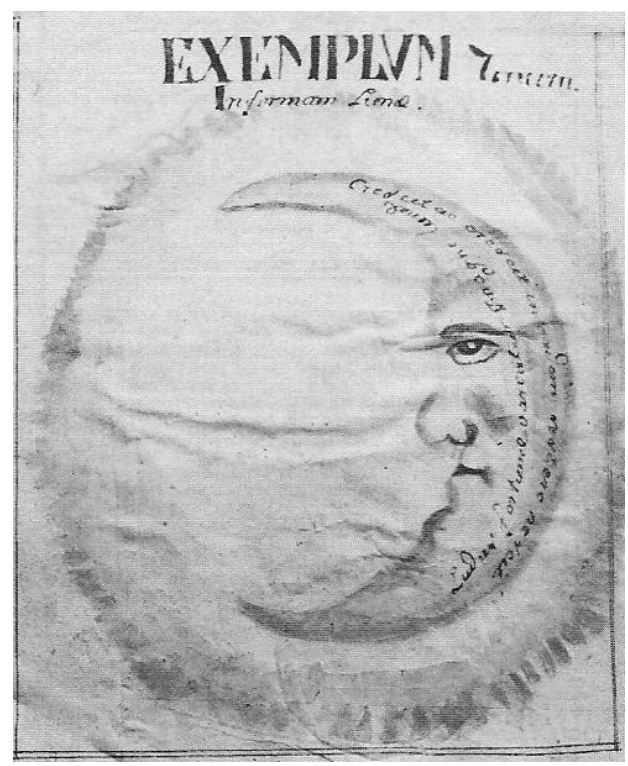

12 Wiersz - serce w języku polskim (1714) (Rypson, 2002, s. 303).

${ }^{13}$ Wiersz wizualny w kształcie półksiężyca, w języku łacińskim (1756) (Rypson, 2002, s. 336). 


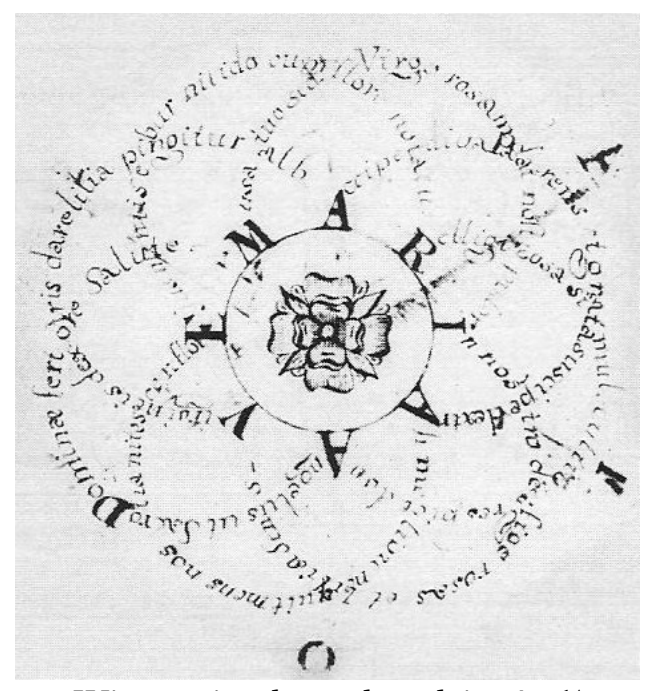

Wiersz wizualny w kształcie róży ${ }^{14}$

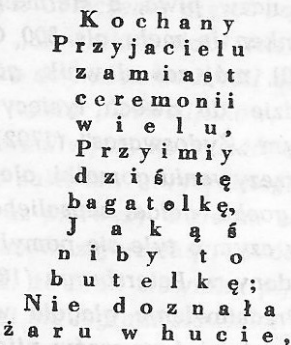

a r a b u c i e,

Ale moie za uczucie.

I źk, toz zaie aię byćpróża,

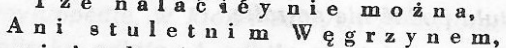

$A n i$ is $d n$ é $m$ i $n$ a é $m$ wi $n$ e $m$,

A iednakże nape 1 n ię ci ią zapewnieniem

Staléy przyiaźni, nayszczerszém źyczeniem,

A ź e býs dózy i a I z tuzina buz razem słyszal: Vivat! Tata!

Byś się z losu twoiego i rodziny cieszy!,

A w pola elireyskie bynaymniéy nie spieszył: Do podeszłego wieku ciągle byl szczęśliwym I noim przyiacielem pozostal prawdziwym. Ié́li ci ta butelka mila Panie Janie.

To iq bez wątpienia powiesisz 1 tak patrząc na nią Jaś sobie pra sianie;

Ze gdy wy prawi bibę musi pić i do mnie,

A iézliby na ten czas zabraknął kieliszek,

To go $\mathbb{z}$ sobbą przyniesie brat Betka Franciszek.
Europejskie doby renesansu i baroku były czasem szczególnego rozwoju poezji, którą można zarówno czytać jak i oglądać. Dobra passa tego rodzaju twórczości $\mathrm{z}$ różnym nasileniem trwała do XIX stulecia, kiedy to zaczęła zdecydowanie zanikać (zob. Bajda, 2010, s. 36-40). Tak też było w Polsce. Z pierwszej połowy XIX stulecia „znane są dwa utwory. Jeden $\mathrm{z}$ nich to wiersz w kształcie butelki z 1822 r. autorstwa Franciszka Betki, drugi anonimowy „kielich” z 1840 r.” (Bajda, 2010, s. 41; por. Rypson, 2002, s. 149-152):

Wiersz - butelka ${ }^{15}$

\footnotetext{
${ }^{14}$ Wiersz - róża w języku łacińskim (1702) (Rypson, 2002, s. 309).

15 Przedruk za: Julian Tuwim (1991, s. 8).
} 


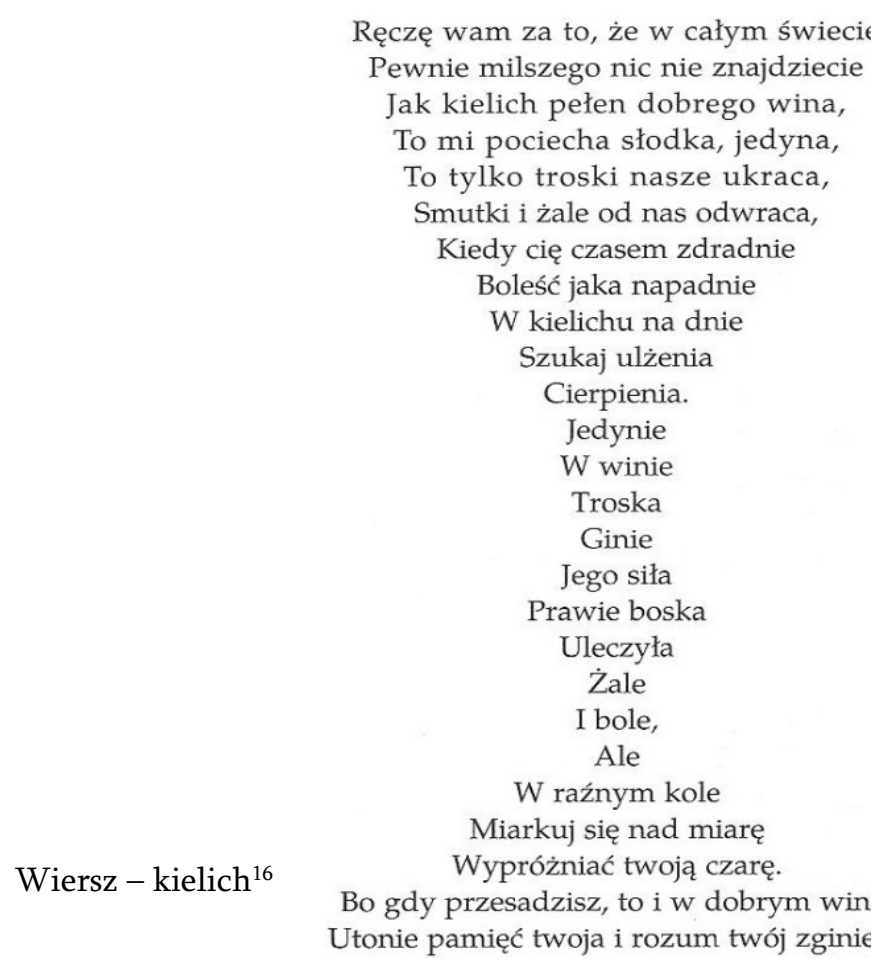

Po swoistym zaniku tego rodzaju wytworów w XIX wieku, poezja wizualna zaistniała ponownie na początku XX. Wówczas typografia zyskiwać zaczęła znaczenie nowoczesne (zob. Bajda, 2010, s. 371-382). Poeci tego czasu chętnie wykorzystują $\mathrm{w}$ swoich prezentacjach wizualnych dziedzictwo tego autoramentu. Z bogatej tradycji czerpie np. polski modernista Tadeusz Miciński, pisząc wiersz o incipicie: Tu znamiona (Miciński, 1902, s. 79) w formie krzyża „dodatkowo wyodrębnionego (...) poprzez zamknięcie tekstu graficznym obrysem" (Bajda, 2010, s. 374-375). Interesującą formą wizualną w tomikach poetyckich wydawanych na przełomie XIX i XX wieku jest tzw. kaskada (od wodospadu) - oryginalny układ wersyfikacyjny przypominający ruch żywiołu wodnego (Grzędzielska, 1963, s. 152).

Ciekawym i oryginalnym twórcą w przedstawianym tu obszarze jest też francuski poeta i prozaik polskiego pochodzenia - Guillaume Apollinaire, właśc. Wilhelm Apollinaris Kostrowicki (1880-1918) (zob. Rousseaux, 1958, s. 7-16). W bogatym dorobku tego twórczego, aktywnego literata znajduje się

${ }^{16}$ Przedruk za: Julian Tuwim (2008, s. 241), tu za: Bajda (2010, s. 41). 
wizualny zbiór wierszy pt. Calligrammes/Kaligramy ${ }^{17}$ (1918). Wyrosły z licznych, różnoimiennych zainteresowań i fascynacji twórcy (od nowoczesnej sztuki i cywilizacji technicznej po banalną codzienność), tom ów przedstawia autorską wizualizację nowych środków wyrazu w poezji. Cechą prymarną jest tu zabawa fragmentem, zdaniem, słowem, jukstapozycja i symultanizm. Świadomie rezygnując $\mathrm{z}$ interpunkcji, operowanie dowolną formą przedmiotów, zjawisk, flory i fauny dawało autorowi Alkoholi (1913) nieograniczone wręcz możliwości koncepcyjne w tworzeniu wierszy, które można czytać i oglądać. Są to bardzo ciekawe koncepty, na przykład list ocean, gwiazdy, krawat, zegar, fontanna, kompas, wieża Eiffla, schody. Kilka egzemplifikacji:

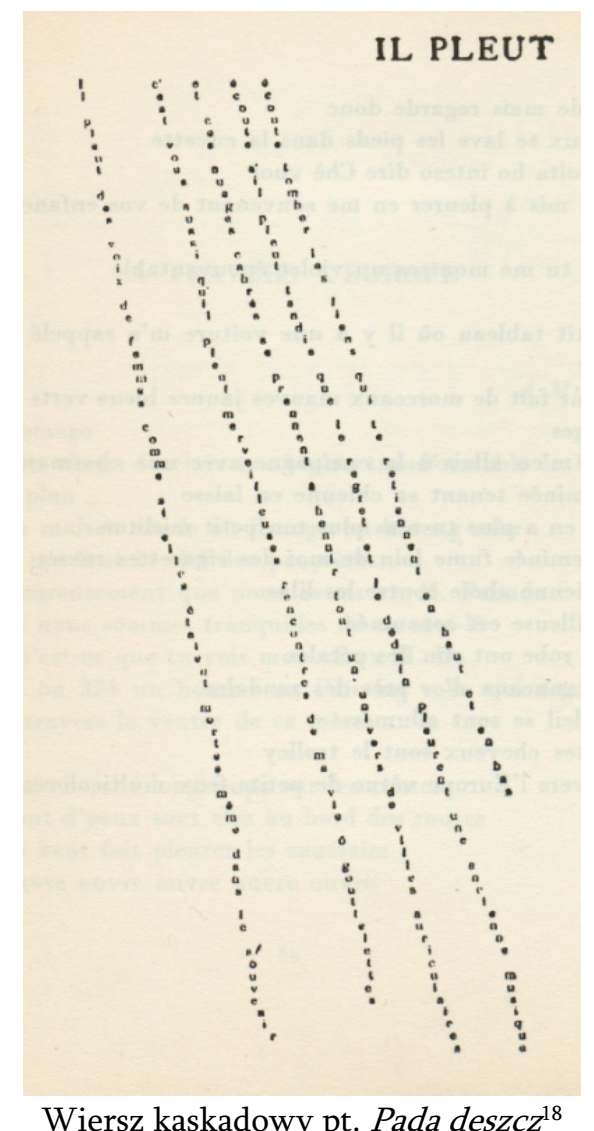

17 Kaligram to forma wiersza obrazkowego, carmen figuratum - wierszowanego, który swym kształtem graficznym przypomina dowolnie wybrany przez autora przedmiot; jest to forma wesołej zabawy poetyckiej.

${ }^{18}$ Guillaume Apollinaire, Il pleut (Apollinaire, 1917, s. 60). 


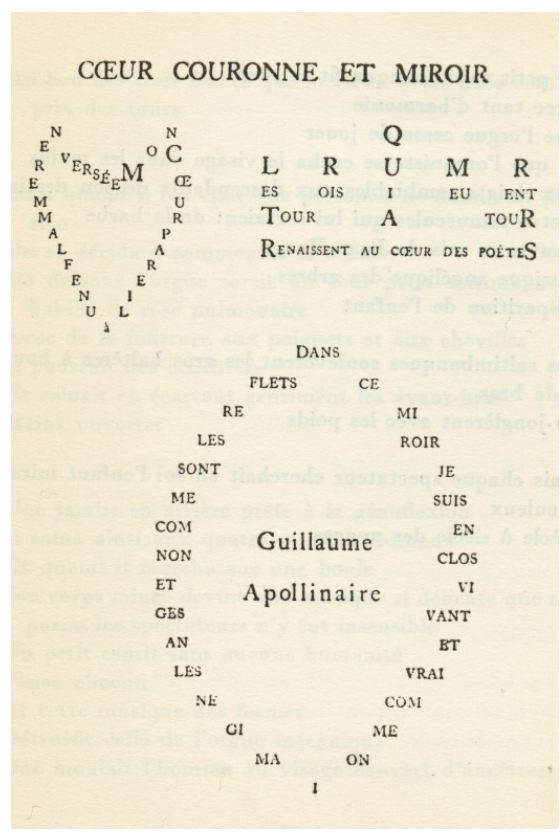

Wiersz pt. Serce korona i lustro ${ }^{19}$

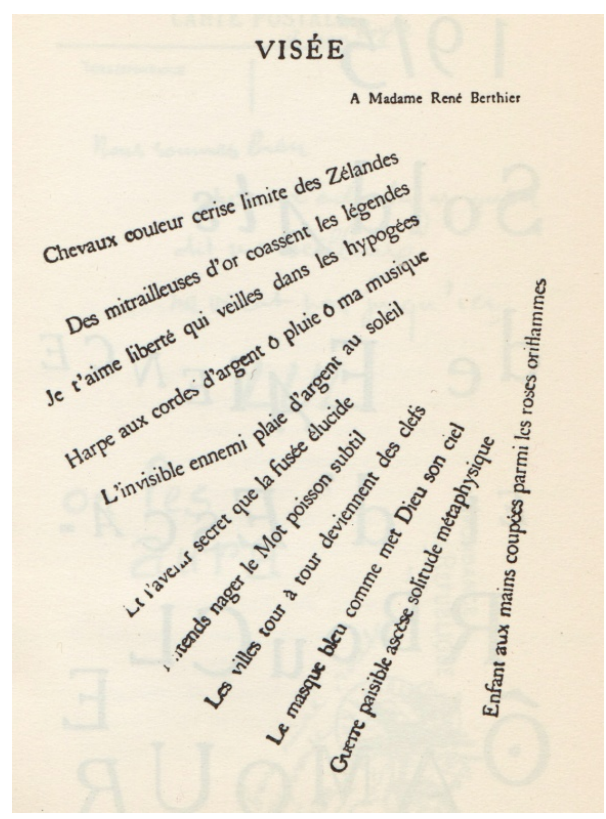

Wiersz pt. Celowanie ${ }^{20}$

19 Guillaume Apollinaire, Cour couronne et miroir (Apollinaire, 1917, s. 54). Tłumaczenie polskie w: Guillaume Apollinaire, Wybór poezji w przekładach Adama Ważyka, „Czytelnik”, Warszawa 1980, s. 149. 


\section{Spojrzenie w komputer}

Słowo ma niezwykłą moc oddziaływania - jest tym niezbywalnym fenomenem, dzięki któremu interpretujemy otaczający nas świat, oceniamy zjawiska, w taki lub inny sposób postrzegamy siebie i innych ludzi osadzonych w rzeczywistości. Dzięki słowom również porozumiewamy się - pisząc i czytając uruchamiamy szczególny proces komunikacji, w którym nadawca i adresat dialogują. Proces ów jest uniwersalny i ponadczasowy, istnieje w każdym międzyosobniczym doświadczeniu. W obecnym momencie kulturowym, w rzeczywistości zdominowanej technologicznie i technicznie, słowo nie znaczy już tyle, ile znaczyło w bogatej tradycji humanistycznej, w olbrzymim dziedzictwie myśli ludzkiej. Zmiana, którą tutaj uwyraźniam, zainicjowała poważny proces przemiany słowa (nie jego deprecjacji), którego konsekwencji doświadcza dzisiaj każdy człowiek - zawieszony chcąc czy nie w cyberkulturze. W niniejszym artykule proponuję przyjrzeć się owej zmianie lingwistycznej jaka dokonuje się na przykładzie poezji cybernetycznej, proponuję spojrzeć na nowatorski projekt „słowa” cybernetycznego, wobec którego wyszła naprzeciw poezja tradycyjna.

\subsection{Pisarstwo elektroniczne}

„Gdyby człowiek zapomniał - pisał Octavio Paz - o poezji, zapomniałby o samym sobie” (1990, s. 139). Paz jako wnikliwy pisarz i myśliciel wyraził w tej ważkiej konstatacji całą istotę fenomenu słowa poetyckiego. Pomimo, iż późna nowoczesność utrwaliła swoisty paradygmat istnienia, funkcjonowania bez kontaktu ze słowem poetyckim $\mathrm{w}$ tradycyjnym paradygmacie, umocniła krzywdzące przekonanie, że we współczesnym skrajnie stechnicyzowanym świecie poezja nie jest potrzebna $\mathrm{z}$ różnych względów. Twórczość z obszaru „liryki” cybernetycznej łamie ten stereotyp, stanowiąc interesującą strategię twórczą dla nowych, „ucyfrowionych” generacji twórców. Katarzyna Otulakowska ${ }^{21}$ odwołując się do Manifestu Poezji Cybernetycznej, przywołuje najistotniejsze pola inspiracyjne twórców cyberpoezji. Oto one:

- Innowacyjna rola i kształt wiersza - „wiersz postrzegany jest jako automat wyrażający niezgodę na tradycyjny język poetycki”;

20 Guillaume Apollinaire, Visé (Apollinaire, 1917, s. 87). Tłumaczenie polskie w: Guillaume Apollinaire, Wybór poezji w przekładach Adama Ważyka, „Czytelnik”, Warszawa 1980, s. 165.

${ }^{21}$ Przytoczenia w punktorach podaję za: Otulakowska (2011, s. 196-197). 
- Komunikacja pisarza z czytelnikiem za pomocą różnoimiennych elementów;

- Poeta cybernetyczny inaczej niż poeta klasyczny posługuje się główną materią poetycką - słowem. Ten pierwszy operuje: „zmutowanymi formami twórczymi": statystyką, teorią informacji, kolażem, montażem, elementami pochodzącymi z cybernetyki;

- „Cybernetyka, scalająca filozofię, sztukę i naukę, na terenie poezji pomaga konstruować nowe narzędzia artystyczne, a także sterować procesem tworzenia. Stąd poeta cybernetyczny sięgnie np. po generator szumów, czyniąc swą metodę pisania zależną od programu, strategii, stając się konstruktorem. Dalej - odwoła się do dobrze znanych pojęć cybernetycznych, takich jak: system, informacja, kod sygnał, sprzężenie zwrotne, szum”[wyróżnienia - P.W.].

Symptomatyczne w dobie aktualnej „konstruowanie” słowa za pomocą różnoimiennych utensyliów technologicznych („pisarstwo elektroniczne” (Pawlicka, 2012, s. 9)) coraz śmielej funkcjonuje, by nie powiedzieć zastępuje tradycyjne, klasyczne „pisanie na papierze”, coraz intensywniej wpływa na kształt poetyckiego oblicza ponowoczesności, uruchamiając niezbity fakt informujący o tym, iż „przestrzeń widzialna przeobraziła się $w$ przestrzeń audiowizualną" (Pawlicka, 2012, s. 9). Obszar słowa drukowanego, pisanego scalił się obecnie ze środowiskiem technologii komputerowych, czego efektem literackim jest właśnie między innymi poezja cybernetyczna. Urszula Pawlicka w swojej książce (Polska) poezja cybernetyczna. Konteksty $i$ charakterystyka wskazuje, iż pojęcie digital poetry pierwszy raz pojawiło się $\mathrm{w}$ przestrzeni użycia powszechnego w roku 1992, natomiast progiem czasowym, od którego w pełni funkcjonuje jest rok 1995, kiedy to wielopoziomowy obszar sieci, wszechobecnego Internetu stał się narzędziem masowego komunikowania. Pierwsza próba zdefiniowania poezji cyfrowej miała miejsce w roku 2004 i „określona została jako projekt artystyczny posługujący się językiem opartym na komunikacji komputerowej i sieciowej” (Pawlicka, 2012, s. 11; 31-33). Pawlicka podkreśla w swoich rozważaniach, powołując się na stanowiska wielu teoretyków poezji cyfrowej, iż uprawianie tego nowego gatunku wymaga od autorów określonej dyscypliny artystycznej, starannego, przemyślanego dopasowania wszystkich składników poetyckiej kompozycji cyfrowej, bowiem dopiero w twórczym ale równorzędnym scaleniu - słowa, fonii oraz obrazu, otrzymać można utwór kompletny. Podstawowymi składnikami - jak podaje badaczka - utworu poetyckiego typu cyfrowego są: znaki literowe, obraz, 
dźwięk, animacja, kolor (Pawlicka, 2012, s. 41). W zasadzie dominuje tutaj wszelka dowolność. Wydaje się, że tak naprawdę w obrębie „tkaniny cyfrowej” połączyć można wszystko i w różny sposób: dodać, dokleić, przesunąć, udźwiękowić, et cetera. Im bardziej wymyślne połączenie, im większa ilość znaków, kodów tym ciekawszy efekt finalny, tym bardziej interesujący produkt mający przyciągnąć odbiorcę. Tak, produkt, bowiem w obecnej rzeczywistości zdominowanej obrazkowo, taki "wiersz” stał się doskonałym medium lekturowym. Przy tak rozległej kompilacji czytelnik, a raczej biorca takich utworów otrzymuje „przekaz tekstowo-wizualno-dźwiękowy”, „cybernetyczny miks" - twór mający za naczelne zadanie chwilowo zainteresować biorcę, zdominować jego sensualność, wypełnić jedynie pewien moment perceptywności, „uderzyć” biorcę określoną dawką silnych bodźców „wywołując poczucie szoku czy transu” (Pawlicka, 2012, s. 70). Wytwór technologicznych możliwości (zob. Śniecikowska, 2014, s. 268-291) - wiersz cyfrowy - jest jednak tworem spłaszczonym. Mam tutaj na myśli różnoimienne ograniczenia tej konstrukcji, z których najważniejszym jest ograniczenie czerpania $\mathrm{z}$ rozległości horyzontu humanistyki. Zauważając, iż słowo klasyczne, zapisane, niesie wiele warstw semantycznych, aktywuje mnóstwo panoram epistemologiczno-aksjologicznych, otwiera człowieka na - co istotne - drugiego człowieka. Zmusza nadto do określonego wysiłku mentalnego, wprowadzając w pożyteczną dla każdej jednostki (choć permanentnie nieuświadamianą) - humanistyczną rewaloryzację. Poezja cybernetyczna natomiast podaje sztuczny, niewrażliwy na rozległość kontekstową produkt, syntetyczny artefakt, p o e m - nie kompozycję wielopłaszczyznowych słów a li tylko „kawałek czasu” między fonią, jakąś jego porcję dookreślającą kształty, kolory, zapachy, kroje czcionek oraz - w niepokojącym nadmiarze - „elementy typowe dla sztuki komputerowej: dystorsję, estetykę błędu i pomyłki" (Otulakowska, 2011, s. 199). Pomimo, iż poezja cybernetyczna jest figuralna, aktywizuje niemal całą indywidualną sensualność człowieka. W dużej mierze jak trafnie dowodzi Otulakowska - cechuje ją „estetyka znikania”, efemerydalność, meandryczność, jest bardziej eksperymentem multimedialnym, niż nosicielką wartości prymarnych.

\subsection{Wideopoezja}

Dobrym odzwierciedleniem tych jakości może być jedna $\mathrm{z}$ odmian poezji cybernetycznej, mianowicie wideopoezja:

Za ojca wideopoezji uważa się portugalskiego poetę Ernesto de Melo

e Castro, który swoje pierwsze eksperymenty $\mathrm{z}$ technologią wideo 
wykonał już w 1968 roku, komponując wideoutwór Wheel Light. Celem artysty było uwolnienie słowa z płaskiej przestrzeni kartki, nawiązując do idei Mallarmégo. Nobilitacja przestrzeni w drugiej połowie XX wieku spowodowała, że Melo e Castro samo pisanie uważał za rzeczywistość trójwymiarową, w której obraz i litery rozmieszczone są przestrzennie i nieustannie przemieszczają się. (...) Dominacja obrazu pojawia się w gatunku wideopoezji, w którym teksty wplecione są w obraz (...), bądź poprzez swój układ konstruują warstwę wizualną (Pawlicka, 2012, s. 94; zob. Kujawa, 2014).

We wszechobecnym dzisiaj obrazie taka aranżacja tekstu okazuje się być bardzo wygodną formą „podania” pewnego fragmentu słów, jak również jego lektury. Szczególnie generacje najmłodsze - kształtowane w kulcie obrazkowości - taki akt lektury przyjmują otwarcie i aprobatywnie. Obecnie, jak wiadomo, czysta (w rozumieniu tradycyjnym) lektura słowa zapisanego na paginach książek nie jest atrakcyjna w takim stopniu jak czytanie, a może lepiej powiedzieć oglądanie tychże. Obraz wideo, podany w rozmaitych wariantach, okazuje się o wiele bardziej atrakcyjny, a nade wszystko o wiele bardziej nośny (!). „Wideopoezja angażuje wzrok, dla którego wyzwaniem jest szybko zmieniający się obraz, zagęszczony wieloma składnikami” - stwierdza Pawlicka (2012, s. 94). Właśnie - angażuje wzrok - i co więcej? W tego typu „dziełach optycznych” jak pisze badaczka, pojawia się istotny, jak sądzę, brak pewnej głębi przekazu, brak czynników, które wyzwalają jakościowy namysł nad rzeczywistością, a nie jedynie powierzchowny ogląd zjawisk - od obrazka do obrazka. W obrazach pokazywanych w różnych kombinacjach dodawana jest muzyka, różnoimienne tony, odgłosy, sygnały albo ciągi pewnych trików multimedialnych mających za zadanie włączyć odbiór sensualny, odłączyć zaś potężną warstwę semantyczną, na której unoszą się słowa. Wideopoezja może stanowić zatem pewien segment doświadczenia eksperymentalnego, obszar awangardy literackiej, reprezentować nowatorskie poszukiwania w osobliwie nawet potraktowanej dziedzinie interdyscyplinarnej aktywności twórczej. Interesującą polską przedstawicielką poezji „wideowej” jest Katarzyna Giełżyńska, która w roku 2012 wydała wideotomik, zatytułowany: C()n Du It. Jest to zbiór „poetyckich klipów słowno-muzycznych”, w których autorka wykorzystuje różnorodne narzędzia internetowe, składowe przestrzeni wirtualnej, budując „wideofraszki” i „humorystycznie ukazuje internetowe rytuały, jak klikanie, czatowanie czy postowanie” (Pawlicka, 2012, s. 97). Projekt Giełżyńskiej jest doskonałym przykładem nowatorskiego ostrzeżenia odczytywanego w sieci i przez ludzi sieci co nadaje mu sens, ostrzeżenia przed 
zatratą podstawowych kategorii humanistycznych (wartość tekstu i autora, zasada uczciwości w korzystaniu z dorobku myśli człowieczej). Skoro zatem „słowo klasyczne” utraciło w jakimś stopniu swoją moc, to może jest szansa, iż palimpsestowe „słowo cyfrowe" dotrze do ponowoczesnych odbiorców z komunikatem o niebezpieczeństwie zatraty wartości (Pawlicka, 2012, s. 98). Katarzyna Giełżyńska walczy swoją twórczością o człowieka pełnego, wielowymiarowego, którego „łowi” w bezmiarze cyfrowego bezsensu, w otchłaniach paradoksów mnożonych przez sieć. Artystka apeluje tym samym o uczciwość, elementarną przyzwoitość, woła poniekąd o przetarcie brudnych okien ekranów i zobaczenie pejzażu uwyraźnionego - krajobrazu z Człowiekiem na pierwszym planie.

\subsection{Liryki cyfrowe}

Urszula Pawlicka w swoich rozważaniach poddaje wnikliwej analizie także inne gatunki poezji cybernetycznej. Są wśród nich takie ponowoczesne wytwory poetyckie jak: cyfrowa poezja konkretna, której cechą prymarną jest „wyciskanie materii języka, czyli testowanie jego najdrobniejszych elementów: słów i liter. Poezja konkretna polega na doświadczaniu utworu, a nie jego rozumowaniu, stąd warstwa semantyczna jest zredukowana” (Pawlicka, 2012, s. 98-99). To kolejny przykład pewnego osłabienia aksjologii zamkniętej $\mathrm{w}$ słowach zapisywanych i wypowiadanych na rzecz komputerowych suspensów, zaciekawienie odbiorcy nie treścią, ale swoistym rodzajem gry multimedialnej, eksplorowaniem pewnych struktur (ustawienie, ruch, włączenie, wyłączenie), obszarów wyprodukowanych przez maszynę. Nader istotny okazuje się tutaj ruch znaków, ikon, obrazów, elementów „gestykulacja tekstu”lub „gramatyka obrazu”(Pawlicka, 2012, s. 99). Odbiorca nie podlega treściom zakodowanym $\mathrm{w}$ słowach, nie odczytuje świata wielopłaszczyznowo, a jedynie podlega złudzeniom wzrokowym, wrażeniom odbywającym się niejako obok jakiejkolwiek semantyki. W cyfrowej poezji wizualnej z kolei, ma miejsce „równoważne połączenie słowa, obrazu, działania i znaczenia" (Pawlicka, 2012, s. 105). Najważniejszą rolę odgrywa tutaj również ruch, który „buduje semantykę obiektu”. Wiersz zatem staje się „obiektem”, w który wbudowywać można elektroniczne gadżety, nadające mu odpowiednie (od)znaczenia. A co zatem dzieje się ze słowem? Słowo staje się jedynie dodatkiem do elektronicznej semantyki obiektu, kolejnym tworzywem służącym „generowaniu mechanizmu”. Utwór poetycki przypisany temu gatunkowi jest cyfrowym konstruktem, software'owym celem składającym się z multimedialnych „warstw, połączonych ze sobą na zasadzie kinetycznej”, 
wewnątrz których „konkretne słowa lub ikony pełnią funkcję odsyłaczy, które należy uruchomić, aby przejść do kolejnej wersji” (Pawlicka, 2012, s. 105). Jaki zatem otrzymujemy efekt? Uszczuplenie rudymentarnej warstwy słów poprzez zastępowanie jej komputerowymi substytutami, to kolejne zaproszenie do komputerowej zasady - klik, klik, klik..., do multilateralnej zabawy w zmienianie sztucznych obiektów na ekranie maszyny. Mechaniczna percepcja, zabawa przyciskami, tymczasowy uskok z jednej ikonosekwencji w drugą.

\subsection{Liryka audialna}

W podobny, perceptywnie spłaszczający obszar wprowadza współczesnego „czytelnika cyfrowego” poezja dźwiękowa, audialna. Pawlicka zwraca uwagę na trzy filary konstytuujące poezję audialną. Badaczka wymienia następujące aspekty poezji audialnej:

- Nowy język mający charakter glosolalii i testowanie jego właściwości fonicznych

- Konstruowanie nowych słów/wyrażeń $\mathrm{z}$ zaproponowanych liter/wyrazów i tym samym komponowanie dźwięku, gdyż każdym znakom literowym przypisany jest dźwięk

- Dzieła konceptualne, które albo eksponują wyłącznie brzmienie poszczególnych liter alfabetu, albo przekładają tekst słowny na dźwięki. (Pawlicka, 2012, s. 108)

Jak wiadomo tradycja sound poetry jest bogata, odwołuje się do ważnych zjawisk $\mathrm{z}$ obszaru świata dźwięków, świata fonii, $\mathrm{z}$ najważniejszym jej przedstawicielem - Hugo Ballem, postulującym „poezję bez słów”. „»Wiersze bez słów" opierały się fonetycznej asonacji, czyli na regularnym powtarzaniu samogłosek”- pisze Pawlicka (2012, s. 109). Artyści z tego kręgu konstruowali ze zbiorów różnych słów, wyrażeń, liter bądź wyrazów nowy język, stanowiący podstawowy budulec dla takiej intensywnej w przekazie poezji, nadając tym autonomicznym tworom inny, niepowtarzalny, abstrakcyjny nierzadko dźwięk. Aliteracja, glosolalia (pozbawione wyraźnego sensu zbitki głosowe tworzące niby-wyrazy), refreniczność, odsączenie znaczenia, to komponenty tego sztucznego języka, „wyzwolonego z reguł lingwistycznych”. Fortunato Depero, Raoul Hausmann czy Marinetti to wiodący poeci audialni. Ich utwory cechuje konceptualność, tworzenie struktur niby-wyrazowych, łączenie dźwięku $\mathrm{z}$ literami, scalanie brzmienia i obrazu, zmienianie zastosowania słów. Szczególnie ciekawa jest koncepcja „słów na wolności” 
Marinettiego, którą przywołuje Pawlicka (2012, s. 109), „polegająca na uwolnieniu słów od logicznej składni i rygorów kompozycyjnych. W efekcie utwór był wolny od zasad syntaktyki, semantyki i od reguł zapisu na kartce papieru. Tekst miał eksplodować na powierzchni strony, poprzez wykorzystanie możliwości typograficznych i przestrzennych”. Aktualnie, w epoce masowej wolności, mody na luz, wszystko staje się dopuszczalne, nawet wieloznacznie brzmiące „wypuszczanie słów na wolność”, o czym świadczyć może na przykład potężna agresja słowna dostrzegalna w przestrzeni publicznej (mowa nienawiści, hejterstwo). Słowo uwolnione od składni i rygorów kompozycyjnych staje się właśnie niby-słowem, pustym dźwiękiem dowolnie formowanym i wykorzystywanym, beztreściowym bibelotem technocentrycznym. Eksperyment Marinettiego czy innych nowatorów, pozostaje jedynie doświadczeniem, próbą, zmianą, zjawiskiem nowofalowym.

\subsection{Liryka hipertekstowa}

Podobnie rzecz się ma $\mathrm{z}$ poezją hipertekstową. Tutaj następuje spotkanie człowieka z martwym ekranem komputera i zabawa w przełączanie, klikanie, dodawanie, przeskakiwanie. Uwaga odbiorcy jest skoncentrowana na ruchu odbywającym się na ekranie oraz na ruchu wykonywanym jego ręką na myszy komputerowej. Użytkownik tylko klika i obserwuje. Myśli za niego obraz zmieniający się na ekranie i wciągający odbiorcę w ów elektroniczny pokaz, nakazujący mu niejako wymuszaną, ustawiczną zmianę, przejście $\mathrm{z}$ jednej powłoki w inną. „Tekst, niczym klaser, zgrupowany jest przestrzennie $i$ powiązany siecią. Odbiorca eksploruje pokawałkowany tekst od środka by wytworzyć między jego elementami nowe relacje” (Pawlicka, 2012, s. 119). Odbiorca porusza się, dryfuje pośród „migoczących słów” (Pawlicka, 2012, s. 120), może mieć wrażenie poruszania się w kuriozalnym labiryncie tekstowych wejść, przejść, zupełnej dowolności w odszukiwaniu tekstów lub ich fragmentów (zob. Karpowicz, 2011, s. 409-434).

Alfabet późnej ponowoczesności tworzą jak widać w świetle powyższych rozpoznan - wytwory technocentryzmu. W związku z faktem rozwijających się obecnie gatunków poezji cybernetycznej, rodzi się pewien niepokój o jakość odbieranych przez biorcę tekstów. Następuje tu bowiem pewien symptomatyczny zgrzyt, zaniepokojenie, czy rozmaite „teksty” powstające w środowisku cyfrowym nie spłaszczają czytelniczego odbioru? Wydaje się, że tak, bowiem jak ów odbiór może być pełny, jeśli człowiek porusza się $\mathrm{w}$ nieustannym chaosie, osobliwym chrzęście, szumie, niejako obok 
tradycyjnego paradygmatu czytelniczego. Człowiek - czytelnik, współczesny odbiorca zamienił słowa na obrazy, dźwięki, grafiki, czyniąc z tych elementów ponowoczesny alfabet (zob. Bohn, 2006, s. 5-25). Natłok obrazowej przestrzeni steruje uwagą współczesnych, słowo klasyczne natomiast staje się jedynie tłem powszechnej komunikacji. Dzisiaj prymarną kompetencją stało się przewijanie obrazków, lekturą zaś kolekcjonowanie różnoimiennych fascynacji technicznych.

\section{BIBLIOGRAFIA}

Apollinaire, G. (1917). Il pleut. W: G. Apollinaire, Calligrammes. (Dessins de La Fresnaye). Lausanne: Mermod.

Bajda, J. (2010). Poeci - to są słów malarze... Typy relacji między słowem a obrazem w książkach poetyckich okresu Młodej Polski. (Acta Universitatis Wratislaviensis, 3245). Wrocław: Wydawnictwo Uniwersytetu Wrocławskiego.

Bohn, W. (2006). Kryzys znaku (przeł. K. Majer). Literatura na Świecie, 11-12 (424-425), 5-25.

Brzozowski, S. (1902). Estetyka poglądowa. Przegląd Tygodniowy Życia Społecznego, Literatury i Sztuki, Rok XXXVII, Nr 36, Warszawa 24 sierpnia (6 września) 1902.

Górska-Olesińska, M. (red.) (2012). Liberatura, e-literatura i... remiksy, remediacje, redefinicje. Opole: Wydawnictwo Uniwersytetu Opolskiego.

Grzędzielska, M. (1963). Kaskada. Zagadnienia rodzajów literackich, VI, 1(10)-2(11).

Karpowicz, A. (2011). Gatunki logo wizualne. Od krytyki języka do krytyki społecznej. Zagadnienia Rodzajów Literackich. Rodzaje i style krytycyzmu, LIV, 2(108), 409-434.

Kujawa, D. (2014). Wideopoezja. Szkice. (Biblioteka „Opcji”, tom 19, pod red. A. Świeściak). Katowice: Stowarzyszenie Inicjatyw Wydawniczych.

Lucas, E. (2017). Oswoić cyberświat. Tożsamość, zaufanie $i$ bezpieczeństwo $w$ internecie. Warszawa: Kurhaus Publishing.

Miciński, T. (1902). W mroku gwiazd. Poezye Tadeusza Micińskiego. (Z rysunkami Stanisława Wyspiańskiego). Kraków: Nakład Autora.

Otulakowska, K. (2011). Duch jest w maszynie. Poezja cybernetyczna jako zaprogramowane piękno. W: E. Wilk \& M. Górska-Olesińska (red.), Od liberatury do e-literatury (s. 196-197). Opole: Wydawnictwo Uniwersytetu Opolskiego.

Pawlicka, U. (2012). (Polska) poezja cybernetyczna. Konteksty i charakterystyka. Kraków: Korporacja Ha!art.

Paz, O. (1990). La otra voz. Poesia y fin de siglo. Barcelona: Seix Barral.

Rousseaux, A. (1958). Lire Apollinaire. W: A. Rousseaux, Littérature du vingtième siècle (s. 7-16), Paris: Éditions Albin Michel.

Rypson, P. (1989). Obraz słowa. Historia poezji wizualnej. Warszawa: Akademia Ruchu.

Rypson, P. (2002). Piramidy - słońca - labirynty. Poezja wizualna w Polsce od XVI do XVIII wieku. Warszawa: Wydawnictwo Neriton.

Seweryn, T. (1932). Indywidualność plastyczna Wyspiańskiego. Kraków: Towarzystwo Miłośników Książki.

Śniecikowska, B. (2014). Dźwięk i ruch - o awangardowej poezji dźwiękowej. Teksty Drugie, 3/2014, 268-291.

Tuwim, J. (2008). Pegaz dęba. Warszawa: Wydawnictwo Iskry.

Tuwim, J. (1991). Polski słownik pijacki i antologia bachiczna. Warszawa: Wydawnictwo Oskar. 
Wilczek, P. (1989). Barokowa poezja wizualna w Europie i Polsce. Prolegomena. W: J. Malicki (red.), Staropolskie teksty $i$ konteksty. Studia (s. 43-79). Katowice: Wydawnictwo Uniwersytetu Śląskiego.

Wilk, E. \& Górska-Olesińska, M. (red.) (2011). Od liberatury do e-literatury. Opole: Wydawnictwo Uniwersytetu Opolskiego. 